\title{
KODUTUS KODUS
}

\section{Sissevaade Peeter Sauteri loomingusse}

\author{
LEO LUKS
}

$\mathrm{M}$

inu hüpoteesi kohaselt tuleb kodu eesti kirjanduses esile valdavalt puuduvana, kadunud koduna (Luks 2014: 731). Kodutuskogemus on kirjandusteoses sageli seotud konkreetse probleemi või motiiviga (nt kodu tegelik puudumine või kaotamine, sunnitud pagulus või vangipõlv, naasmine pika äraoleku järel võõraks jäänud koju), mis suunab ühtlasi teose tõlgendamist. Ent selles artiklis tuleb vaatluse alla kodus as et leidev kodutuskogemus, milles puudub selge probleem ja esiletungiv põhjus - tegemist on kodutuskogemuse äärmusliku juhtumiga. Eesti kirjanduses avaneb see kõige puhtamalt Peeter Sauteri teostes.

Kodutus kodus tundub esmapilgul vastuolulise mõistena. Kui lähtuda tavakeelsest arusaamast, siis oleks kodu kui püsiva elupaiga olemasolu kodutust välistav tingimus ja vastupidi. Kuid olen kodu(suse) määratlenud fenomenoloogiliselt inimlikule olemisele omase kogemushorisondina, mis seisneb igapäevases toimimises, hoiab käigus argielulisi seoseid ja pakub seeläbi turvalisust (vt Luks 2013a: 410-414). Kodususe kogemushorisont ei hõlma mitte üksnes ruumilist, vaid ka intersubjektiivset elementi, piisavalt turvalisi ja mõttekaid suhteid kodukaaslastega. Kodutuse olen määratlenud isiklikult kogetava, olulise, ajaliselt püsiva kodusushorisondi tõrkena (Luks 2013a: 415). Horisondid üldisemalt, sh kodusushorisont, jäävad kogemuses n-ö nähtamatuks ning muutuvad teadvustatuks just tõ rke korral. Horisondi tõrge tähendab kogemuse vahetust sujuvusest distantseerumist ega ole tingimata negatiivse väärtusega asjaolu: tõrge võib olla ka pidulik-pühalik (nt kodu ülistamine pidulaulus, vt Luks 2014: 733-735) või tingitud kodususe üle teoretiseerimisest.

Nii kodususkogemuse ruumiline kui ka intersubjektiivne mõõde ei piirdu kodu kui privaatse ruumi ja perekonna kui intiimsete kodukaaslastega, vaid avardub, hajudes sujuvalt võõrusse. Kodususkogemus vajab struktuurse paarilisena võorrust, inimese eluilm jaguneb samaaegselt koduilmaks ja võõrilmaks (vt Luks 2013a: 412). Kujutlus alati turvalist kodususkogemust hoidvast kodust on parimal juhul nostalgiline unistus. Ka kodu intiimses sfääris ähvardavad inimest ohud, mis võivad tekitada kodutuskogemust. Näiteks on ühiskonnas üha teravamalt esile kerkinud koduvägivalla probleem, aga ka lõviosa narratiivsetest kunstidest tiirleb lähisuhtemurede ümber. Sarnanevad ju kõik õnnelikud perekonnad üksteisega (Tolstoi 1957: 5) ega paku kirjandusele ainest. Kodu sõnaski peitub ebaõdusus (vrd sks heimlich/unheimlich, vt Luks 2018: 182) ja inimene kui määramatusele avatud olend on olemuslikult kodutu (vt Luks 2013b: 1113-1118). 
Artiklis võtan vaatluse alla Peeter Sauteri romaanid „Indigo” (1990, edaspidi viidetes I), „Luus” (1997, L) ja „Beibi bluu” (2008, BB) ning neli olustikuliselt tihedalt seotud ja rõhutatult autobiograafilist proosapoeemi: „Märkmeid vaeste kirjanike majast” (2012, VKM), „Koer ostab kassitoitu” (2014, KOK), „Pannkoogid üksinduses” (2015, PKÜ) ja „Kodusõdur” (2018, KS). Keskendun nende teoste ühtsele peategelasele, kes on tuttav juba „Indigost” ja keda iseloomustab passiivsus, kohmetus, joomine, pingeline suhe lähimate kodukaaslastega (kui neid on), negatiivne hinnang oma seisundile. Sauteri teoste niisuguse peategelase elu varjutab asumisprobleem, mida nimetan k od u t u seks kodus. Uurimus tugineb fenomenoloogilisele arusaamale kodutusest (Luks 2013a). Artikli esimeses osas kirjeldan vaadeldavate teoste kodutuskogemust, tuginedes peategelase sisekõnele, ning seejärel analüüsin selle kogemuse ruumilist, intersubjektiivset ja tegevuslikku aspekti. Teises osas käsitlen kodutut, võõrdunud subjektiivsust, vaadeldes seejuures, kuidas see subjekt määratleb oma positsiooni maailmakõiksuses. Kolmandas osas käsitlen Sauteri teoste peategelase püsiva kodutusseisundiga toimetuleku strateegiaid, jõudes seeläbi neljandas peatükis kirjutamisprotsessi kui ühe peamise toimetulekustrateegia analüüsi juurde. Viiendas osas tõlgendan Sauteri peategelase seisundit eksistentsiaalsete tunnete kontseptsiooni abil (Ratcliffe 2012) ning osutan põgusalt teistele võimalikele tõlgendussuundadele.

Peale selle, et Sauteri looming on oluline kodutuse kirjandusliku kujutamise näide, väärib mainimist ka asjaolu, et kuigi Sauterit on peetud XX sajandi lõpu eesti kirjanduse proosauuendajaks ning tema teoseid on palju arvustatud, leidub tema loomingule keskenduvaid uurimuslikke artikleid hämmastavalt vähe (Sering 1992; Krull 2000; Heinloo 2009). Tõsi küll: mõnes artiklis on Sauterit käsitletud riivamisi või teiste seas (Annus 2009; Kraavi 2016).

\section{Läbistav kodutus}

Kodutus on kõikide vaatlusaluste Sauteri raamatute minategelase läbiv seisund, kui hetkelised kodutustunde katkestused välja arvata. ${ }^{1}$ Seda deklareerib peategelane korduvalt oma sisemonoloogis, nt „Pole kodus ka siis, kui kodus oled" (I: 170). Ta ei leia asu (I: 120) ega oma kohta elus, sageli istub ta kodus kurva ja kurjana, kodutundeta (VKM: 79), nimetades oma eluaset uruks (L: 276), kongiks (Sauter 1998: 80) või puuriks (KS: 86). Mis peamine: ta keeldub omaks võtmast koduste argiaskelduste rutiini. Ent selles omaksvõtus peitubki n-ö kodunemise valem. See keeldumine hõlmab nii lähisuhteid („Me lihtsalt ei viitsinud asutada koduperekondlikku majandusüksust, mis meid koos hoidnuks" - L: 149) kui ka suhtumist ruumi. Peategelane ei soovi lõplikult juurduda, kodu omada, vaid eelistab elada justkui külalisena: „Rõõmustasin, et ei saanud mingit kapitaalset oma elamist ega teinud kapitaalset remonteerimist. Sest vaat kui pärast ei olegi seal oma unistuste korteris hea. Siis on ju jama." (L: 148)

${ }^{1}$ Sellest meeleolust eristub vaid „Märkmeid vaeste kirjanike majast”, mis on Sauteri raamatutest kõige kodusem ning tuleb eraldi vaatluse alla hiljem. 
Rutiinist keeldumine iseloomustab ka suhtumist töösse neis vähestes tekstides, kus peategelane püsivalt töötab. „Beibi bluus” leidub peategelase tulevast põhiseisundit ette kuulutav sõnum: „Aga ma tean siiani, et ühel päeval panen jälle käed tasku ja astun tööuksest välja ja polegi enam töötegija. Töötegemine ei tohiks muutuda harjumuseks [---].” (BB: 111)

Kuid kuidas kulgeb see argirutiinist keelduv elu? Kas otsitakse aktiivselt erilisi sündmusi, kuhjatakse erinevaid reisimuljeid, ${ }^{2}$ armuseiklusi, ekstaatilisi pidustusi? Või tuleb peale kohustustest-muredest vaba olemise kergus? Sugugi mitte. Peategelase põhiseisundiks on hoopis ängistav tardumine argielu tõrkesse, piinav igavus ning esiletungiv teadlikkus kodutusest. See seisund ei võimalda midagi teha, isegi mitte lugeda (I: 49). Tõsi küll, siin on esiteks kohal ka ebamäärane millegi parema ootus ${ }^{3}$ ning harvad helgusehetked (sh kodusushetked) - neid vaatlen allpool eraldi. Peale selle on tegevusest loobunud subjektile omane mõtete vaibumise taotlus, kuid see ei täitu, üldine meeleseisund on rusuv ja ärev.

Jään koju ja kannatan ära mittemidagitegemise närvelduse, ühest toast teise jalutamise. Igavuse ja tühjuse. Aga homme õhtul tuleb ju seesama. (I: 130)

Siis, kui pole mingeid muresid ja võiks rahu ja hea tulla, ei tule mingit rahu ega head. Hakkab kuidagi igav ja tülpinud, magamised venivad pikaks. Mõtled oma olemise, iseenda ja oma sandi elu peale. (L: 141)

Harva, kui on hea molutada, enamasti on see häda ja hingepiin. (BB: 108)

Utreerides võib öelda, et n-ö tavaline elu ei ole Sauteri raamatute minategelase jaoks elamisväärne, kuid ka sellest distantseerumine ei paku rahuldust. Kuidas avaldub Sauteri teostes kodutus ruumilis-intersubjektiivsel teljel, mis on käesoleva uurimuse aluseks oleva teooria kohaselt (Luks 2013a) kodususkogemuse struktuuri universaalne osa? Sellele küsimusele ei ole võimalik ainuüksi teooria toel ammendavalt vastata, sest seisundi põhjuseid tuleb otsida üldisemalt, eksistentsiaalselt-metafüüsiliselt tasandilt. Kuid vaadeldes kaht kodusust võimaldavat aspekti - ruumilist ja intersubjektiivset -, julgen väita, et Sauteri kodusushorisondi tõrgete kirjeldamisel d o m i n e e rib intersubjektiivne aspekt.

Alustan siiski ru u mist. Nagu olen kirjeldanud varem (Luks 2014: 739), võib kodusushorisondi ruumiline tõrge tähendada ennekõike seda, et inimese elupaik tundub võõras, ei toesta identiteeti, ei võimalda suhteid ega sidet ajalooga, muutudes seeläbi kohast mittekohaks (Augé 2012; vt ka Luks 2013a:

2 „Indigos” on siiski äratuntav kodus konutamise ja linna vahel või tuttavaid mööda hulkumise vahelduv režiim, kus viimane tegevus on eelistatum, vähem ängistav. Sellele tähelepanekule on oma tõlgenduse üles ehitanud Ivo Heinloo (2009), kes käsitleb „Indigo” peategelast moodsa aja flanöörina. Sauteri järgmistes teostes on hulkumine aga üha vähenenud ja peategelane areneb oma elupaika kapseldumise suunas. Mõtisklused liikumisest-kulgemisest on Sauter koondanud kahte autobiograafilisse reisiraamatusse (Sauter 2005, 2011).

${ }^{3}$ „Mis on see suur, mis läbi aastate toitu annaks, vee peal hoiaks? On ainult äraharjumine. Kodu, tool, hambahari, habemeajamisriistad, naine. Ei taha nii. Leppida on rumal, viselda on rumal." (I: 213) 
410). Selle tõrke puhtaimaks näiteks on ouduskirjandus oma ebaõdusate ruumidega, mis muutuvad enamasti kummitusmajadeks (vt Boscaljon 2016), kuid ebaõdus ruumisuhe toimib kirjanduses sageli ka sümboolsel tasandil (nt Juhan Liivi must lagi) (vt Luks 2014, 2018).

Sauteri teostes ei esine ruumilist painet peaaegu üldse. Peategelase suhe elupaiga ruumiliste aspektidega on enamasti hajameelne ja neutraalne. Väga harva pannakse tähele ja kujutatakse elupaika täpsemalt: nt novellis „Kodu ja muu" kirjeldatakse ruumide kaupa vanemate ehitatud maja, millega peategelasel on „[m]ingit üsna imelikku pistmist” (Sauter 1998: 50). Peategelane arutleb, et maja on pisut suur ja küllap oli osa tube mõeldud õdedele-vendadele, keda talle ei tulnud, ning et isal pole vist hea tunne maja talle pärandada - ruumiline kõhklus kandub seega sujuvalt üle inimsuhetesse.

„Indigos” kirjeldab peategelane mõnevõrra oma tuba, näiteks et see on enamasti poolsegamini nagu tema isegi (I: 13). Kuna oluline osa Sauteri teoste sündmustikust möödub peategelasel kodus konutades, kirjeldatakse parasjagu nähtut, kuid sedagi kiretult-neutraalselt (vt I: 188), ning sageli vaadatakse lihtsalt aknast välja (I: 123) või kuulatatakse väljast kostvaid hääli. Võib siiski leida mõne koha, kus kirjeldatakse ängistust nii, nagu see tekiks mõne kodus tajutud ruumilise detaili kaudu: „Kraan tilkus köögipoolel. Tegin silmad lahti, vaatasin lakke ja kuulasin, kuidas kraan masendava järjekindlusega tilgub. Poleks ime, kui maja selle peale viimaks kokku vajuks.” (I: 133)

„Indigos” sedastatakse küll, et pole ruumi (I: 13), kuid ülekantud tähenduses: elatakse vanemate juures ega iseseisvuta, vanemad „hoiavad vee peal” ja soosivad vegeteerimist. Seega on ruumiline sedastus siin metafoorne, intersubjektiivne.

Sauteri peategelasel ei ole elupaigale peaaegu mingeid nõudmisi. „Luusi” viimases osas kolib tegelane lobudikku linna servas (L: 249), üksildasse urgu (L: 276), kuid kusagil ei mainita, et see keskkond kuidagi rohkem ängistaks. Vaeste kirjanike maja tsüklis koguni kiidetakse agulielu (VKM: 7-9, 112-114), muuhulgas ahju kütmist, mis on hubane tegevus ja aitab mõttevoogu peatada (PKÜ: 8-11). Peategelase eespool mainitud rõõmu laenatud pinnal elamisest arendab Sauter hiljem sümboolseks identiteediloome manifestiks:

\author{
kodu ei tohi remontida \\ liiga ilusaks \\ muidu tulevad külalised \\ ja hakkavad laiutama \\ mõni jääbki minu juurde elama \\ ja teeb minu kodust \\ endale kodu \\ ja minust \\ elukaaslase \\ kodu peab olema \\ sama vastik \\ kui ma ise \\ siis on siin hea \\ konutada \\ oma elemendis \\ vastikud asjad peas
}


ja südames

ja minu ümber

(KOK: 65)

Ka Sauteri peategelase elupaigast pisut kaugema suhtes ei väljendata mingit ebalust või võõristust. Tegelane kulgeb linnaruumis probleemideta, hajameelselt, tajudes intensiivselt detaile ja hetkes avanevaid olukordi (vt ka Heinloo 2009). Kuigi „Indigo” peategelane elab ilmselt Mustamäel ja Sauteri poeemide kangelane pendeldab Uue Maailma ja Lasnamäe vahel, puudub Sauteri poeetikas kivilinna-magalarajooni ebaõdusust tekitav vari. Kogu Tallinn on selle tegelase jaoks tuttav kant ega ole seotud kodutuskogemuse tekkimisega: „tallinn on vist ümar // nagu maakera / ja tal on need paralleelid ja rööbikud / midapidi leiab tagasitee / sest kuhu sa ka hulgud / ikka jõuad õnneks / varem või hiljem / koju tagasi" (PKÜ: 48).

Vaatlusalustes raamatutes esineb ka mõningaid kummituslikke nägemusi, kuid need ei ole seotud ühegi konkreetse kohaga, vaid avanevad siseilmas. Kord kardetakse tumeda kuju ilmumist uksele (BB: 105), siis ilmuvad unenäos apokalüptilised hobused (KOK: 112-114) või liigutakse irreaalses ruumis laste laipade keskel (KOK: 118-120). Viimast nägemust seletatakse suhetega: painaja ilmub isale, kes oma laste eest ei hoolitse ega mõtle nendele kuigivõrd (KOK: 118). Korraks avaldub küll klassikaline ebaõdususe tekkemehhanism, unenäoline sattumine tuttavasse, kuid võõraks muutunud ruumi, aga see pole tegelase elupaik, vaid töökoht (VKM: 167). Esineb kirjeldus peategelase suunataju kaotusest lennujaamas (KS: 13-17), kuid olukorra kirjeldus ei kutsu seda tõlgendama Augé vaimus anonüümsete mittekohtade pealetungina meie ruumisuhetesse. Suunataju kaotus on Sauteri tegelase jaoks erandlik sündmus, mille seletust võib otsida pigem joomisest, ning probleemi teravik kandub ka siin suhetesse, sest tema armsam ja reisikaaslane jättis ta paanikahoos üksi, minnes ise lennukile.

Ruum ei toimi seega Sauteri loomingus kodutust põhjustava elemendina. Seda enam tuleb esile kodutuskogemuse in tersubjektiivne tasand, täpsemalt öeldes probleemid lähimate kodukaaslastega. „Indigos” ning mõnes 1990. aastate novellis („Kodu ja muu”, „Tuimus”) esineb ebamugav ja pingeline minategelase suhe vanematega, hiljem muutub probleem võimetuseks koduneda lähisuhtes. Seevastu avaramas koduilmas (külaskäikudel, juhuslikel kohtumistel, kokkupuutumistel võõraste vastutulijatega) edeneb suhtlus paremini. Näiteks „Luusi” kolmandas osas jagab minategelane varjupaigas öömaja erinevate eluheidikutega, kellega lähestikku viibimine ei tekita temas mingeid tõsiseid tõrkeid.

Sauteri tegelase võimetust kodu kellegagi jagada ei ole lihtne taandada mõnele levinud põhjusele, nagu põlvkondadevaheline vastuolu või mäss sotsiaalsete normide vastu. Ehk vaid novell „Kodu ja muu” pakub selget tõlgendussuunda: introvertset ja tundlikku minategelast häirib nii ema-isa jahe ja tüliderohke suhe kui ka see, et omaette nokitseva fotograafina ei vasta ta oma vanemate ootustele, pole n-ö tegija. Seevastu „Indigos” on ema-poja suhe vähemalt näiliselt delikaatne ja teineteist aktsepteeriv, ema ei survesta logelevat minategelast paremat elu alustama ning toetab tema eksirännakuid rahaliselt. Minategelast ei iseloomusta ka süümepiinad sotsiaalsetest normidest 
kõrvalekaldumise tõttu. Ta aktsepteerib sisekõnes oma eriskummalisust ja eluviise, nt ema juures elamist või sinna tagasikolimist ja hiljem, poeemides, laste rahalise toeta jätmist. Just võimalikku normaalsesse argiellu neeldumist käsitletakse suure ja ebameeldiva ohuna: „Kõik teised teevad ju sedasama. Noh, saavad mingi lapse ja mingi naise ja mingi kodu nagu teisedki, ja kui siis tööl ei käi nagu teisedki, siis hakkab ängistama.” (BB: 110-111)

Ka lähisuhete kriisidel ei ole Sauteri teostes kunagi konkreetset põhjust. Kooselud lihtsalt ei suju ja vajuvad laisalt ära, nagu „Luusi” teises osas, või arenevad tüliderohkeks seisundiks „Beibi bluus” ja viimase kümnendi poeemides. Ei paista, nagu elukaaslased nõuaksid minategelaselt mingit teistmoodi eluviisi, suuremat panustamist suhtesse, lihtsalt ollakse omavahel ärevas, tõrkuvas läbisaamises.

Kuid Sauteri tegelasele ei paku kodusust ka üksindus. See ei kehti mitte üksnes poeemide kohta, kus tegutseb armastusest sõltuvuses subjekt, pendeldades piinava koosolemise ja omaette virelemise vahel (KOK: 14). Üksinduse ebamugavus iseloomustab ka varasemate teoste peategelast, keda Epp Annus on tabavalt nimetanud ihatuks ja rahu otsivaks (2009: 139). Kuigi mõnikord kirjeldatakse vanematekodus ajutiselt üksi viibimist kui head olemist, harva kodusushetke (Sauter 1998: 41), muutub pikemaajaline üksi elamine ängistavaks molutamiseks, nagu peatüki alguses osutasin (vt L: 276-277), ning võtab kohati luupainajaliku nägemuse mõõtmed (KOK: 146).

Mis imelikus paradoksis Sauteri peategelane elab? Ruumi ja intersubjektiivsuse kategooriad ei võimalda antud olukorda piisava täpsusega seletada. Toon siinkohal mängu veel ühe argielu ja kodusust iseloomustava kategooria: praktikahoris on di (vt Luks 2013a: 408). Nagu näitas Martin Heidegger, ei kulge igapäevaelu mitte erinevate asjade ja sündmuste järgnevusena tajuväljas, vaid just praktikaseostena, kus erinevad käepärased esemed viitavad sujuvalt üksteisele, ilma et neid kuigivõrd pingsalt tajutaks ja tematiseeritaks. Alles siis, kui selles seoste tervikus tekib tõrge, muutub üks või teine ese käegakatsutavaks objektiks, mida tähele pannakse. (vt Heidegger 1967: 66-83)

Sauteri peategelane, kes väldib tegutsemist ja argielus osalemist, elabki peamiselt just praktikahorisondi tõrkes, kus asjad ei viita üksteisele, vaid tungivad painava intensiivsusega tajuvälja, ning kus sündmused ei haaku ja aeg ei kulge sujuvalt, vaid aeglustub kõhedateks hetkedeks ja venib igavuseks (KOK: 146). Tõrkes elav tegelane ei neeldu praktilistesse askeldustesse nagu tavapärases argielus, vaid on ärevil, alati eemalt vaatamas ning vajab pidevalt rahunemiseks alkoholi. Mõistagi häirib selline distantseeritus peategelase kodukaaslasi, seega tekib Sauteri tegelasel tõrge ka argise üksteisega koosolemise kui praktikahorisondi suhtes.

Sauteri peategelane pole nõus eksistentsiaalset ängi maandama toimiva argieluga, temas peituv distants ei võimalda kooselu, aga ka eraklik üksindus ei sobi - kas sellele probleemile leidub mingigi lahendus? Peategelase toimetulekustrateegiaist, millest teen lähemalt juttu ülejärgmises peatükis, leiab siiski ühe mudeli: nn elamine külasolijana, balansseerimine kodususe/kodutuse, suhete/üksinduse piiril. Tuttavlikkus ja mõttekad suhted tuleb jaotada nõnda, et mõttetuse esiletungiv paine oleks pisut vaigistatud, kuid samal ajal ei neelduks subjekt argielu banaalsusse: 
Üksinda olla, kuskil teiste läheduses. See on üsna hea.

Ühes toas, kui keegi teine on kõrvaltoas. Ja õues sajab.

Üksi, aga tuttavatest asjadest mitte kaugel.

Oma kongis, teiste kongide lähedal. (L: 157-158)

Vaeste kirjanike maja võiks olla peategelase jaoks just selline koht, kus ümberringi, kuid siiski teisel pool seina on omad inimesed (VKM: 138), kellega akna peal juttu rääkida (PKÜ: 94); kus „kõik on kõigiga suhtes / üksteist omamata" (KOK: 132) ning argiellu neeldumist takistab pidev, kuid siiski mitte tappev vaesus (VKM: 112). See võiks ollagi teatav kodususe mudel, kui poleks armastusest sõltuvust, mis lõhub leebet rutiini.

\section{Võimetu subjekt mõttetus maailmas}

Vaatlusalustes teostes on läbivaks hoidumine targutamisest, igasuguse filosoofia umbusaldamine (KOK: 164-166) ning minajutustaja määratlemine lollina (BB: 124), tarkadeks arutluskäikudeks võimetuna. Ometi ei piirdu Sauteri minategelase teadvusvoog üksnes kodutuskogemuse väljendamisega, seosetult kuhjates konutava tegelase teadvusse argiseid hetki. Juba alates „Indigost” sisaldavad Sauteri teosed niisuguseid abstraktseid väiteid, mida võib nimetada metafüüsilisteks, olgugi et nendeni ei jõuta range filosoofilise arutluse kaudu. Sauteri raamatud ei sisalda ainult argist ebaõdusust, vaid ka kategoorilisi väiteid metafü üsiliste alusmõistete (maailm, elu, olemine, aeg, mõttekus) kohta ning samuti kodutuse käes vaevleva tegelase subjektiivsuse aluskategooriate (ajataju, keelekogemus) kirjeldusi. Mõistagi põimuvad metafüüsiline ja subjektiivne tasand Sauteri teostele omases vabas mõttevoos pidevalt, kuid on siiski eristatavad.

Alustan metafüüsiliste arutluskäikude vaatlust makrokosmosest. Sauteri tegelaste jaoks on maailm tühi, juhuslik ja mõttetu:

See on lihtsalt, et näed, et maailm on tühi ja mõttetu ja inimmõistuse olemasolu mõistusetus maailmas on pentsik ja inimese käitumine on pentsik. (L: 263)

Maailm on juhuslik. Mõtlemine on seosepõhine. Mõtlemine on teistsuguse konstruktsiooniga kui maailm. Maailmas on ka seoseid, aga maailm ei põhine seostel.

Jumal vajutas nuppu „random”.

Juhuslikkus tundub talumatu. Mõtlemist ja maailma on raske vastavusse viia. (BB: 16)

teadvus ei talu

maailma seletamatust

õppida seda taluma

oleks ehk ainuke

mida natuke õppida

vaevalt küll

et see saaks nii selgeks 
et taluks tühjust ja seletamatust

rõõmsalt ja muretult

ka surres

(KOK: 22)

Arusaamani maailma mõttetusest ja juhuslikkusest ei jõuta mitte filosofeerimise teel, vaid seda kogetakse-tajutakse vahetult, tühja elu vaakumina (I: 5), kuristikkudena (I: 37) või olemisse tekkivate aukudena, mille käigus vajutakse argisuhtlusest kuhugi ära (I: 15). Mõttetuse tundmine jõuab äärmusse järgmise tõdemusena:

Midagi ei ole, midagi pole olemas olnud, midagi ei tule. Kes minevikku ei mäleta, see elab tulevikuta. Ja see on kena. Olla eikeegi eimiskis. Sõnad ju on, ma kirjutan sõnu, on mõtted, aga nad on seest tühjad, nad on vorm, seest tühjad anumad, mis ei tähenda mitte midagi. (I: 110)

Siin pole siiski tegemist ontoloogilise mõtteharjutusega, vaid poeetilise väljendusega, toomaks esile afektiivne põrkumine negatiivsusega. Mitte midagi, st mitte midagi mõttekat, turvalist, juhib Sauteri peategelase elu tervikuna: elatakse „ei kuidagi” (I: 86), „mitte mingit elu” (I: 40), võimetuna tegutsema. Selles mitteelus pole ka ühtegi väärtust, mille poole püüelda:

Väärtusi tahaks. Aga neid pole kuskilt võtta. Välja mõelda pole mõtet. Kuskilt ei saa. Jäävad ainult järgnevad hetked ja järjest kerkivad väikesoovid ja seisundid: nälg, üksindus, seltskond, jook, tüdruk, uni, kodu, tühjus; igapäev ja väikesoovid. (I: 131)

Eimiski käes virelemises tardutakse hetke või sellesama mõttetuse eristamatusse kordumisse, mis väljendub aj a pu udu mis e teesis (I: 114; L: 177).

Mis on olnud, see ei kao. Ma olen seda kogu aeg teadnud, et see nii on, aga ma ei tea, kuidas see nii on. Nii on üldse asjadega, mida ma tean. Ma tean, mis on, aga ma ei tea, miks või kuidas. Sellepärast, et miksi ja kuidasit polegi olemas. Asjad on päriselt, aga miks ja kuidas on ainult peas. (BB: 12)

See, mis on, on mõttetu ja juhuslik, kuid inimlik mõtlemine ei sobi säärase immanentsuse kogemiseks ja keel selle vahendamiseks. „Sõnad pole eesmärk, sõnad on vahend. Aga seda, mille saavutamiseks või mille tegemiseks nad vahend on, pole olemas." (BB: 131) Tundub, et autentseks olemiseks tuleks vabaneda seostatud mõtetest ja selgete tähendustega keelest. Sauteri teoste peategelane üritab seda korduvalt, kuid edutult („Ei saa mõtlemisega mõtlemise vastu" - I: 206). Siiski püüab ta nihestada tuttavaid tähendusi, liikuda võõrusse (L: 270), olla avatud tähenduseta mõtete tulvale: „Mitte midagi lõpetada, kui tore, ma ei lõpetaks peas ühtegi mõtet, ühtegi lauset, ühtegi sõnagi. Vaatan ainult ringi: kõik möödub kuidagi imelikult." (I: 114)

Etteruttavalt: kirjutamine on peategelase jaoks üks selline tähenduste hajutamise praktika (vt käesoleva artikli 4. osa). 
Mis iseloomustab seda subjekti, kes seisab pidevalt ja vältimatult silmitsi eimiskiga, kõige mõttetusega, kellel on „loomulik olemise kompleks” (L: 269), kelle meeleolu on enamasti negatiivne ning kelle jaoks luhtumise $\mathrm{m}$ it t e moodustab kogemuse kõige üldisema emotsionaalse horisondi (,aga kui troostitut kurbust / ei õnnestu kodustada / ja omaks mängida / ja ta kestab ja kestab / ja tapab ajataju ja mõtted / ja sööb ära kõik teised tunded / ja sööb ära ka minu [---] siis ma olen lihtsalt väga väsind / väsinud mittemillestki / mittemiski ongi kõige väsitavam" - VKM: 136)? Millised hoovused kulgevad selle mina sügavuses? Seni kirjeldatu põhjal saab öelda, et see mina on püsivalt kodutu. Fenomenoloogilise kogemusteooria järgi on maailm (eluilm) kõige üldisem kogemushorisont (Luks 2013a: 407-408), mille alusel seotakse argielukogemused. Kui subjekt elutseb pidevas kodususe tõrkes, mõjutab see ka kõige üldisemat kogemushorisonti, maailma. Heideggeri varasema fenomenoloogia järgi ongi maailm ontoloogilises mõttes tein e, eimiski, millega liiga lähedalt kokkupuutumine tekitab inimeses ängistust, kuid ometi pole inimesel kogemuse ja tunnetuse piire ületava olendina võimalik seda kokkupuudet vältida (vt Luks 2013b: 1116-1117).

Kõikides vaatlusalustes Sauteri teostes tegeleb peategelane enesemääratlusega ning läbivaks jooneks on ebamäärane, laialivalguv enesetaju. Kuna sõnad on ebausaldusväärsed, seest tühjad, pole võimalik ennast keeleliste vahenditega määratleda, ka sõna mina on „üsna tühi” (BB: 132). Tegelane ei tea, kes ta on (I: 125), ei suuda ennast väljendada, kuna sõnad on võõrad (I: 6). Keelelisest tähendusest distantseeritus avaldubki jõuetuses, tahtenõrkuses (I: 49), soovimatuses millestki osa võtta (I: 6), tundes, et mis tahes tegutsemine on elu raiskamine (I: 89), ning neutraalsuses, hoiakute ja suhtumise puudumises (I: 181).

Kuigi seda ebamäärast enesetunnetust ei ole võimalik defineerida, kirjeldab minategelane seda siiski kaudselt ja metafoorselt - eriti kujundirohkeks muutub see kirjelduskeel Sauteri poeemides. Endast mõtlev mina ei saa iial täiskasvanuks (I: 177; VKM: 88), ta on tükk sülti, keda peaaegu ei olegi olemas (I: 153), „kokkuvarastatud tükk”, kus midagi pole päris oma (PKÜ: 26), kogu eksistentsi arusaamatuse üle kurvastav neegerori (PKÜ: 106-108), arenemisvõimetu tõuk (KS: 9) jne.

Säärane hajuv mina justkui ei sobi ellu, teda kannab tunne, et elu möödub tema osavõtuta (I: 179): „Elu on meist väljaspool ja tal pole meiega asja” (BB: 102). See tunne tekitab ebaõdusaid katkestusi argises kogemusvoos:

Mina olin - jah, kus ma olin? - ma polnud päris surnud, aga ma olin kuskil mujal, ei tea, kus, igatahes mitte siin. Ma ainult mängisin, et ma olen siin, istun töötoolil ja teen tööd. Ma olin nagu zombi. Ja oleksin tahtnud tagasi ellu. See elu oli justkui klaasi taga. Ma nägin inimesi elamas, aga nad olid klaasi taga. (BB: 84)

Kummituse kujund enesemääratluse vahendina esineb ka Sauteri hilisemas loomingus. Peategelane tajub ennast iseenda vaimuna, kes kummitab vindisena Koidu tänava korteris (KOK: 128-132) ja kes tahabki „olla poolelus poolsurnud / ja kummitada väsimatult" (KOK: 130). 
Üldiselt on aga minategelase soovide ja tahtmistega keerukad lood. Juba Sauteri teoste varaseimates käsitlustes on kilbile tõstetud kreedo olla eikeegi eimiskis (I: 114; vt ka Sering 1992), saada lahti tähendustest, vaibuda:

Ise ei olegi keegi. Ja ma tahaksingi olla Eikeegi. See oleks puhkus. Tahaks ainult endasse võtta kõik selle, mille keskel ma olen elanud. [---]

Selles oleks uhkust ja ilu ka. Olla Eikeegi. Või eikeegi. Või null. (I: 153)

Passiivne oleskelu enamasti ei tekita peategelases soovitud mõteteta puhkuse seisundit. Kas ennast kirjeldav teadvus on siis alles poolel teel ise lakkamisse, surma, nagu võib välja lugeda eeltsiteeritud kreedost? Kas olla Eikeegi tähendab sedasama mis lakata olemast? Sugugi mitte ning Sauteri looming ei suundu kunagi surma poole kirjutamisse (erinevalt nt Jüri Ehlvestist, vt Luks 2015, ptk 7). Siiski harjutab Sauteri poeemide peategelane kõike aktsepteerivat hoiakut ka surma peal (KOK: 96-100), tundes küll aeg-ajalt nördimust ja võõristust tuttavate suremise üle (VKM: 20-21; KOK: 58-59), kuid kirjeldades samal ajal helgetes toonides poja Kusti kaotust: surnud poega hoides oli isal hea lähedane tunne (KS: 106), mis kordus surnukeha põlemise ajal krematooriumis, ahju ees istudes (KOK: 100).

Hoolimata surmaga lähedalt seotud hetkedest ei söösta Sauteri peategelane surma, vaid otsib eikellenagi-olemist eluviisina, omamoodi askeesina. Soovi võtta endasse kõik, mille keskel ollakse elanud, täpsustatakse:

[---] kui sind kaua millegagi piinatakse, siis saab lahenduseks, et sa ei puikle enam, vaid võtad oma piina vastu ja lahustud sellesse, rõõmus nägu ees, saadki selleks, kelleks sind tahetakse teha. (I: 153)

Aga parim on, kui oled lihtsalt paigal, ainult mitte surnud, vaid pakatav, kõik möödub, kõik voolab järjest sinu sisse. (I: 154-155)

Korduvalt esineb Sauteri teostes episood, kus peategelane hakkab vajuma täielikku passiivsusse, kuid siis võpatab üles (I: 188; BB: 115).

vajan tüli iseendaga

et leida uut algust

tööisu ja enesearmastust

ja mitte ainult tiksuda

vindise metronoomina

ôlleklaaside taga

(KOK: 137$)^{4}$

„Luusi” peategelasele meenutab südamesse lööv valu surma, aga just „see teeb tähelepanelikumaks elu vastu" (L: 179). Seega säilib Sauteri peategelases kõige mõttetusele vaatamata elusäde, otsitav eikeegi on teistsuguse eksistentsi viis, mis oleks vaba elule omastest majanduslikest seostest. Selle ülesleidmiseks tuleb sõnade levinud tähendused kõrvale heita ja oodata:

${ }^{4}$ Täieliku vaibumise vastu aitab ka näiteks pidev kolimine (VKM: 93-96). 
Pean olema hästi vaikne, et keegi, kes on minu sees ja kes on minust tähtsam, pääseks minu seest vangist vabaks. Võibolla on see tõeline mina. Seni on tõeline mina, Tark Mina, minu teadvus vangis. Miks see nii on, seda ei saa vist iial teada. Sõnades ei ole vastust. (I: 171)

Näiteks „Luusi” kolmandas osas loodab peategelane, kes on läinud pagulusse Liverpooli, olla eikeegi eikuskil tänu võõrale keskkonnale, kus juurdunud suhted ja plaanid ei ahistaks.

Aga mina olen siiski võõras, üksik, tundmatu, ilma vähimagi rahata, pidepunktideta, eesmärkideta, nagu ma Tallinnas alati olla tahtsin, aga ei saanud, sest oli liiga palju seoseid ja tuttavaid, tehtud tegusid ja nende tegude tagajärgi kõikjal ümberringi õhus hõljumas. (L: 197)

Sauteri teoste peategelane ei söösta surma, kuid elu on tema jaoks mõttetu ja kulgeb justkui distantsilt. Olukord on paradoksaalne või isegi traagiline, sest kodutu võõruse piin jääb kestma. Neeldumine n-ö korralikku ellu koos selle pisimuredega, sh perekonna pidamine ei õnnestu peategelasel kuidagi (vt L: 268). Kas ainus, mis üle jääb, on oma piina vastuvõtmine, püsiv kodutu vegeteerimine iseenda vaimuna? Seda oleks rohkem, kui inimene kannatada suudab, ja see peaks lõppema teadvuse kollapsiga, hullusega. Kuigi Sauteri teostes flirditakse põgusalt hullusega (I: 205), siis peategelase fragmentaarsed kogemused ning isegi painavad nägemused on selgepiirilised ja jälgitavad, samuti säilitab Sauteri looming lausete tasandil alati loetavuse.

Sauteri teoste subjekt balansseerib kodususe ja kodutuse piiril, otsib eluga parajat distantsi, mis võimaldaks nn eikeegi-olemist, kuid ei hävitaks teadvust. Kodutuse piinavas öös leidub siiski ka lohutavaid hetki, mis aitavad mõttetut eksistentsi kanda. Järgnevalt asungi neid hetki vaatlema.

\section{Kodused hetked}

Esitan põgusa loetelu kogemustest, mida võib vastukaaluks Sauteri peategelase üldisele elutundele nimetada mõttekateks ning positiivseid emotsioone tekitavateks. Nende kogemuste kaudu tuleb välja ka seisund, mis Sauteri teostes on nimetatud k odususeks.

1. Ma agilised hetked. Sauteri peategelane ei konuta kogu aeg ängistunult oma elupaigas, vaid hulgub ka selle ümbruses. Aeg-ajalt teravdub tema tajuväljas mõni inimene või olukord, nõnda et avaneb olukorra laiem kontekst, isegi selle osaliste meeleolud. Ivo Heinloo seletab neid hetki flanöörile omase terava pilguga (Heinloo 2009: 94-95) ning Hasso Krull näeb neis teravdunud suhet teisega, milles tajutakse mingit saladust (Krull 2000: 100-102). Mõnikord tekib positiivset meeleolu ka peategelase privaatsesse argikogemusse, milleks võib olla kas või õnnestunud sitalkäik (L: 156-157). Just niisuguste hetkede täpne ja intensiivne tunnetamine ja kirjeldamine nõuab sellist sisseelamist, mille juures maailma mõttetuse äng ei saa domineerida. Teksti kui terviku tasandil toetab metafüüsilist mõttetust-juhuslikkust asjaolu, et maagilised hetked jäävad isoleeritud fragmentideks, mis ei arenda süžeed. 
2. Leige pendeldamine. Üks meetod, mis aitab nii toime tulla metafüüsilise ängiga kui ka hoiduda kindlasse elumustrisse juurdumisest, tundub Sauteri teostes olevat mitmekesiste ruumi- ja inimsuhete hoidmine. „Indigos” väljendub see kodus istumise ja hulkumise vaheldumises, samuti selles, et elatakse justkui võõrsil: ema juures ning lühemaid perioode pruutide juures. Samasugune pendeldamine kordub teistes teostes ja see seostub eelnevalt avatud motiiviga mitte liialt juurduda, kohustuste ja ootuste alla mattuda ehk taotlusega olla mitmes kohas kodus. „olen kodus sel maal / mitmel pool / kodusel maal / kuigi kodutu / kodutul ongi mitu kodu / ja nii on hea" (VKM: 12).

Omamoodi kodusus tekib peategelases isegi tuttavasse baari „kadunud pojana" tualetti asjale minnes (PKÜ: 108-109). Nii üritatakse tasakaalustada üksindust ja seltsi, lähedust ja distantsi: „hea tunne oli / olla korraga üksi ja võõras / ja kodus / ja oma" (PKÜ: 110).

3. Tuimastid. Põhiline tuimasti on Sauteri tekstides teadagi alkohol, mida pruugitakse rutiinselt, joomine ei tekita eufooriat, kirgastumist ega humoorikat nihet tegelikkusetajus. Alkoholi tuimastavat, üksindust vaigistavat funktsiooni tunnistab peategelane ise (I: 209; KS: 61). Mõnikord aitab mõtteid vaigistada ka mõni monotoonne töö, näiteks ahju kütmine või värava värvimine. „Olen jõudnud oma päristegevuse juurde, lihtsa üksildase käsitöö juurde, millel pole suuremat mõtet ja mida saab teha tasuta. Kusjuures söögi ja öömaja eest on hoolitsetud. See on jõudmine paradiisi.” (L: 189)

4. Armastus ja armumine on oma intensiivsuses küll negatiivne, kuid rebib peategelase tardumusest välja. Armumise kirjeldusi leidub juba „Indigos” (I: 87-88, 157-159, 195-196; „Luusis” areneb abieluks suhe Reksiga), kuid fookusesse tõuseb armastuse probleem Sauteri poeemides. See armastus ei ole rahulik ega õnnelik, vaid pigem sõltuvus (PKÜ: 57), lõks (KS: 38), ometi hoiab see peategelast käigus, nii et pendeldamine üksindust pakkuva ateljee ja armsama korteri vahel pole enam sugugi leige.

5. Harvu kodusushetki leidub juba „Indigos”, nii emakodus kui ka pruutide juures. Nende tekkimine ei ole küll seotud mingi kindla toiminguga, kuid peategelane paneb neid tähele ja kirjeldab hoolikalt:

Vahel harva tuleb eriline õilis kodusolemise feeling, nagu ekstaas. Oled mõnuga kodus, ümbrus soojusest värvitud, teed midagi vaikselt või istud, molutad ja jälgid ümbrust, ja kõik ümberringi on imeline. Tuba, valgus, kõik; vaatad aknast välja - oleks nagu ilus koht see majaesine, just sellisena nagu mõnes lasteraamatus, kodu. (I: 37, vt ka 49, 51, 123; BB: 36-37)

Kodusus ei saa aga püsivaks-tavaliseks kogemushorisondiks. Tõsi küll, kodususe olemust mõistetakse: „kodu on enamasti vaikne tegelane / nagu ema või vanaema / peerule ja rõõmule / lihtsalt fooniks ja dekoratsiooniks" (VKM: 127). Ent kodusust esineb Sauteri peategelase jaoks harva ja see tungib esile pigem maagilise hetkena, kui pidev kodutuse tõrge äkitselt katkeb. Niisiis on Sauteri teostes kodusushorisont kogu aeg nähtav, teadvustatud, sest tõrge selles on püsiv, lihtsalt kodutusseisundi tõttu tekkinud tõrge asendub mõnikord mõne teist laadi tõrkega, milleks on kodu poeetiline-pühalik nimetamine ekstaatilistes kodususe kirjeldustes. 
Kõige kodusem Sauteri raamat on vaieldamatult „Märkmeid vaeste kirjanike majast”, kus intensiivne kodususe kujutamine on kohati suisa hümnilik. Ühel konkreetsel hetkel kodususe üle mõtiskledes kirjeldatakse kodu ruumilist ja intersubjektiivset aspekti, rõhuasetusega viimasel. Lähtekohaks võiks võtta tõdemuse, et kodu on tu n n e, see, kui „on hea / et kingitud kell on käima hakanud / ja näitab ilusat aega / ilusas ruumis". Kodutunde hädavajalik element on kodukaaslased: „mis see kodu on? / see on kui inimesed on kodus”. Kirjeldataval hetkel on kodus tütar Siskin ja armsam Laura, kes mõlemad tukuvad, ning vististi tütre sõbranna Diana („sest kodu vajab ka külalist”), kes näpib oma kärna ja sööb selle ära „nagu mina lapsena / kärn maitseb hea / ja see ongi kodu". (VKM: 78-79) Idülli raamistab rahu, keegi ei tüüta minategelast. Pole ohtu, et maagilises hetkes hakkaks keegi kamandama või sisse seadma kodukorda. Kodususe tekkimiseks ja püsimiseks on vaja lähedust, mis samal ajal ei lämmataks, seejuures pole füüsiline kohalolu põhiline: „tahan tunda end kodus / kogu aeg ja kõikjal / selleks peab teadma / et ootad mind / ja siss ootab / ootus hoiab kodu alles" (VKM: 82).

Lähedustunne muudab koduseks ka elukoha: koduselt sädeleb tolm riiulitel ning poja Kusti tuhaurnil (VKM: 78) - kodutunne hõlmab ka surnud lähedasi. Hiljem seda mõtet võimendatakse: „ehk on kodu ka surm / kusti imaginaarne laip / millest mitu kuud / veel üle astusin / toas ja esikus” (VKM: 82). Kodune tundub ilus räämas ruum ja kõik, mis aknast paista on (VKM: 78), samuti kempsu- ja keldrihais (VKM: 80). Koduseks võib muutuda ka mõne sõbra kodu, park või õhtune tänav, „kogu see räämas linn / ja metsane maa” (VKM: 128). Koduhõllanduses muutub isegi jumal tuttavaks tegelaseks, külaliseks (VKM: 80). Siin-seal muudab Sauter ka kauged metafüüsilised kategooriad omaseks, õdusaks (VKM: 84-86; KOK: 133; PKÜ: 169-171), poeetilise ülekande abil kodustatakse ka maailm: „et maailm on kodu / sest on raske sotti saada / pole igasse nurka sülitanud / iga põõsa taga magand // samas on ta tilluke ja taskupandav / pliiatsiteritaja" (VKM: 82). Varasemas proosas üksnes unistati niisugusest poeetilisest võttest: „Kui saaks tõusta maakerast kõrgemale. See aitaks teda kodustada. Enam poleks nii kaotsis. Väike maa. Ehk tõusen sinna." (L: 278)

Sauteri peategelase elu kulgeb kodutuse vaevas, mida õilistavad harvad pidulikud kodusushetked. See on esmapilgul kummaline ja äraspidine asumine kodutuses, kodukäija elu, mille kirjeldamine kummituse metafoori abil (KOK: 128-132) on igati ootuspärane. Kuid kui rõhutada asjaolu, et Sauteri poeemide peategelane identifitseerib end poeedina (VKM: 28), siis heidab see ehk tema hämarale asumisele veidi valgust. Nagu olen oma artiklite seerias üritanud näidata, on kodutus (eesti) kirjanduses loomulik olek, poeet jääb alati kodukäijaks, kes ei leia asu. Vaadelgem seega järgmiseks, kuidas avaneb Sauteri tekstide kodutushorisondil kirjanikuks olemine ja kirjutamisprotsess.

\section{Kirjutamine on kodu}

Sauteri varast proosat analüüsides tõdeb Hasso Krull, et seal ei jutustata eriti kirjutamisest (Krull 2000: 107). Kuni „Beibi bluuni” jääbki kirjutamisprotsess teoses nähtamatuks, autori hääl ei sekku peategelase sisekõnesse ning pea- 
tegelane ei kirjuta ega identifitseeri ennast kirjanikuna. Neljas vaatlusaluses poeemis on aga vastupidi: lüüriline mina sarnaneb vägagi autoriga ning arutelud kirjutamisprotsessi üle on sagedased.

Nagu öeldud, Sauteri kodutult asuv, piinlev inimene umbusaldab keelt, seda, et sõnade tähendused saaksid väljendada olulist. Nõnda tekib oletus, et kirjutamine on piin, Blanchot' (1999) vaimus ängistus, kuna midagi olulist pole võimalik öelda ning kirjandus rebib kirjutava inimese elust välja, imaginaarsesse piinavasse kirjanduslikkuse ru umi (paradigmaatiliseks näiteks on Kafka). Kuid see oletus ei ole Sauteri puhul õige - hoolimata eespool avatud üldisest sõnade tühjuse kogemusest. Novellis „Tõlkija” väljendab kirjutamisest keelduv peategelane küll pieteeti keele müstilise funktsiooni suhtes: „Tõelised asjad vaibuvad sõnamulinasse. Aga sõnakunst on see: rääkida rääkimise ja rääkimatuse piirimail. Kus sõnastamatu on lähedal ja laseb oma juuresolekut tunda." (Sauter 1998: 73) Kuid säärane hoiak ei ole laiemalt Sauteri tekstidele omane.

Üldiselt on kirjutamine Sauteri peategelase jaoks kerge, tekstimasin liigub justkui ise ning elustab pisut tardumusse vajunud, tegutsemisvõimetut subjekti: „aga kui viitsin tekstimasina käivitada / ärkan tibake ellu / tekst elustab mind / ja ma teen elusat teksti / perpetum mobile / ja muud tööd / ei taha ei oska ei õpi" (VKM: 48). Peategelane ei häbene seejuures tunnistada, et kirjutamistung teeb temast grafomaani (VKM: 115-117), ta ei karda sündmuste pidevat kordamist erinevates tekstides. Kirjutamine erineb seejuures rääkimisest: kõneldes peategelane kogeleb, komistab, ei tea sõnade tähendust (L: 270), kuid kirjutades on ta vaba ja julge: „kirjutada võin kõigest / ja praalida / a kui suu lahti teen / tuleb mök-mök" (KOK: 72). Isikliku kogemuse piires kõigest häbenemata kirjutamist on Sauteri teksti eripärana ammugi tähele pandud (vt Krull 2000: 92). ${ }^{5}$

Kirjutamine on tuttav-turvaline rutiin, olgugi et ängistava eksistentsi ja traumaatiliste sündmuste kirjeldamine on peategelase hinnangul omamoodi nartsissism, masohhism ja sadism, kuid samal ajal ka teraapia (BB: 126), mis aitab elada (KS: 39). Kirjutamine on üks vähestest protsessidest, millesse kogemushorisontide tõrgete käes vaevlev subjekt saab neelduda - just neeldumine tuttavlikkusse ongi minu teoreetiliste lähtekohtade alusel kodusus (Luks 2013a: 410-414). Seesama mõte esineb ka Sauteri tekstis: „kirjutamine on kodu" (VKM: 39). Erinevalt ruumis paiknevast elupaigast on paberil asuvas kodus alati hea olla ning sinna tahetakse tagasi tulla, seal võib muretult olla ise või mängida kedagi teist, kutsuda alati külalisi, et oleks kellestki kirjutada (VKM: 39-43). Teisal nimetatakse kirjutamist suisa metafüüsiliseks koduks, viisiks asuda kadunud kodus:

Arvuti taga oma teksti kirjutades olen ma justkui mingis metafüüsilises kodus, Ernst Enno kadunud kodus (kahtlustan, et ka Ennole, kes luuletustes tolle müstilise kadunud kodu järele igatses, oli kirjutamine koduks või vähemalt kodu aseaineks). (Sauter 2011: 114)

${ }^{5}$ Tõsi küll, poeemides on sauterlikku avameelsust pisut vähem, esineb isegi vihjelisust. Kuid tuttav piirideta avameelsus avaneb Sauteri kahes viimases romaanis (Sauter 2012, 2016), mille põhjalikum analüüsimine lisaks juba vaadeldavatele tekstidele polnud artikli vormis mahuliselt võimalik. 
Kas Sauteri kirjutamiskodu on välj a mõ eld is, mis võimaldab elu painetest vabaneda? Või kui vabanemine alati ei õnnestu, kas kirjutav subjekt vähemalt taotleb elust distantseerumist? See pole siiski nii, kuigi mõned üksikud kirjakohad võivad sellist tõlgendust toetada: „kirjutamine on unenägemine / ja peale selle une / palju muud ei tahagi vaadata" (KOK: 27). Kuid Sauteri teosed ei loo fantastilisi faabulaid, unenäoruume, vaid registreerivad sedasama ebamugavat ja mõttetut elu, mille käes minategelane vaevleb. Tõsi küll, Sauteri poeemides on fantaasiale varasemast rohkem voli antud ning argine virelus vaheldub minategelase kujutluspiltide tulvaga.

Kirjutamise sidumine eluga ei ole üksnes poeetiline kujund, vaid sisaldub selgesõnaliselt kirjutamise kui kodu kontseptsioonis. Teose „Märkmeid vaeste kirjanike majast" 15. peatükis ei jää kirjutamine argisest maailmast lahutatud sfääriks, vaid põimub sujuvalt füüsilise ruumiga, milles kirjutaja asub. „[E]sialgu aitab kirjutamiskodustki / vaeste kirjanike majas” (VKM: 40) - nende ridadega liigutakse poeemis imaginaarsest ruumist tegelikku, mõeldes, mida parajasti teevad minategelase kirjanikest naabrid. Sama võte kordub: „praegune kodu / kirjutamine koidu uulitsas / on ka paras ühikas ja klooster" (VKM: 42). Kirjutamise kodusus ilmneb aegruumis ning „värvib” ka korteri koduseks. Sama efekt esineb peegelpildis poeemi 32. peatükis: seal ei ole küll temaatilises fookuses kirjutamine, vaid kodususidülli hetk aegruumis, kuid just n-ö kaadri taha jääv kirjutamisprotsess, poeetiline nimetamine on see, mis muudab vaikelu hubaseks ja pühalikuks. Minategelane on pühaliku nimetamisakti käigus elu seostest kõrvale astunud, piisavalt turvalisel kaugusel - kirjutamas. Hiljem suudab seesama, kirjutamiskodus võimendatud meeleolu muuta koduseks teisigi paiku: sõprade kodud, räämas linna ja metsase maa (VKM: 128).

Kirjutamine on Sauteri peategelase jaoks läbinisti eluline ja positiivne toiming. Juba „Indigos” meenutab peategelane helgelt sõjaväe ajal emaga peetud kirjavahetust: „Ma ei ole emaga iial nii hästi läbi saanud, kui kroonust kirjutades" (I: 143). Hilisemates tekstides avanevad mõnikord ka kirjutamiseks vajalikud tingimused ja seda takistavad tõrked. Näiteks takistab kirjutamist see, kui ei jooda (VKM: 74) või kui keelatakse kirjutada kõigest: „kui sa olid endast kirjutamise / mulle ära keelanud / ja ma neli päeva / üldse ei kirjutanud / tundsin et see on põrgu / kui ei tohi kirjutada" (KOK: 26). Hiljem jõutakse äratundmiseni, et kirjutamine ei edene, kui pole naist: „naine peatab mõtlemise / ja et kirjutada / ei tohi mõtelda" (KS: 100).

Kirjutamisse ei tohi uppuda, kuid see oht on alati olemas, balansseerimine kirjanduse ja elu piiril on raske:

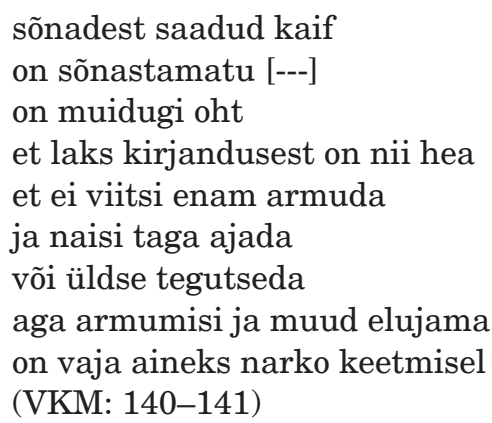


Niisiis, kirjutamine on Sauteri teoste peategelase päriskodu, mis võimaldab mõttetut elu pisut hubasemaks „värvida”. Selleks et kirjutamine toimiks, on vaja teatavaid tingimusi: argisekeldustest täitmata jõudeelu, aga ka intiimsust ja armastust, mis samal ajal ei lämmataks ega muutuks kohustavaks. Vajalik tasakaal kirjutamise ja elu vahel tekib harva ning püsib lühikest aega, nendel maagilistel hetkedel tunneb peategelane ennast koduselt ning ülistab kirjutamist koduna. Ent enamasti asub minategelane kodutult, kodutus kodus ning üha kirjutab seda luhtumise seisundit läbi - ka kirjutamiskodu on sel juhul ebaõdus, seega on peategelane topelt kodutu. Kõigele vaatamata hoiab see tegelane piinavast elust kramplikult kinni, ta jätkab kirjutamist ja elutsemist kodutus kodus.

\section{Kodutus eksistentsiaalsete tunnete põiminguna}

Kahtlemata saaks Sauteri tekstides avanevat kodusust-kodutust, seda veidralt kodutut ehk kodutus kodus viibivat subjekti analüüsida $\mathrm{ps}$ üh ho a n a lü üsi võtmes: põgusalt on selle tee avanud Hasso Krull, tõlgendades Sauteri tekstide ängistust Asja liigse ligioleku tundmisena (Krull 2000: 98-100). Subjekti iseendale võõras olemist on analüüsinud mitmed psühhoanalüüsist tõukuvad teoreetikud (Kristeva 2017; Hamblet 2003).

Kindlasti ei jääks Sauteri peategelase tõlgendamisel jänni psühhia atriat tundvad teoreetikud, küllap võib teostest leida märke depressioonist, autismist ja veel millestki. Sauteri tekstid pakuvad hulganisti ainest peresuhetele keskenduvaks tõlgenduseks: minategelane tunneb puudust vanemate emotsionaalsest lähedusest nii lapsepõlve meenutades (VKM: 33) kui ka reaalajas $(\mathrm{I}: 7,13)$ ning toob seda mõnikord esile põhjusena, miks tal ei õnnestu luua emotsionaalselt turvalisi lähedussuhteid (KS: 18). Mitmed kodutuse tõlgendajad (Sibley 1995; Wardhaugh 1999) teevad ettepaneku keskenduda koduseinte vahel pidevalt asetleidvale vägivallale ja vaevale, tegeleda kodususes peituva ebaõdusa saladusega.

Kerge vaevaga võiks Sauteri peategelase kodutust tõlgendada aja stuja ühiskonnakriitiliselt kui globaalsele kapitalismile omase, tehnilistel suhetel põhineva elu tühjenemist tähendustest ja õdususest. Sellist laadi kriitilisi analüüse on ka kodutuse mõiste varal tehtud (Lyotard 1991; Dovey 1985: 51-59; Kramer, Lee 1999; Pallasmaa 2008), seejuures ka ilukirjandust uurides (Männiste 2013). Tasub meenutada, et „Indigot” tajuti ilmumisajal sageli stagnatsiooniaja noorsoo eluhoiakut avava põlvkonnaromaanina. Siiski arvan, et Sauteri teoste ühiskonnakriitiline tõlgendus nõuab päris suuri jõupingutusi ja juurdekirjutusi, kuna need ei sisalda peaaegu üldse ühegi konkreetse ühiskonnakorra kriitikat, vaid nendes hüpatakse isiklikult elukogemuselt otse metafüüsilisele tasandile.

Kui rõhutada peategelase elujaatavat külge ning Sauteri tekstide suundumust tuua transtsendentsed tähistajad immanentsusse (jumal või Jeesus sõbrameestena köögis juttu puhumas jne), võiks tõlgendus areneda Gilles Deleuze'i (2001) tuules elu kui puhta immanentsuse kogemuse piiritlemiseni. 
Sauteri peategelase radikaalne keeldumine tööst ja asjalikest askeldustest võimaldab inimloomust piiritleda nii, nagu Giorgio Agamben (1999) on käsitlenud inimest kui viivitajat, potentsiaalsuste valdajat, kes ei neeldu tegelikkusse (vt Lipping 2016).

Tegelase mõtlemise vaibumist taotlevad otsingud ning metafüüsilised visioonid mittemillegi olemasolu kohta avavad budistliku tõlgendusliini, mille kohta esineb põgusaid vihjeid ka Sauteri teostes, tema ühe raamatu pealkiri ja peamine tõlgendusmotiiv on koguni „Flirt budaga” (2011).

Rõhutades peategelase seletamatut ängi ja igavust ning seda tekitavat mittemiskit, võib Sauteri loomingut tõlgendada varase Heideggeri vaimus ontoloogiliselt, maailma transtsendentsi avanemisena inimese kogemusele (Heidegger 1983).

Kõik mainitud tõlgendused tunduvad huvitavad ning ootavad aega, mil Sauteri uurimine saab hoo sisse. Omalt poolt pakun siinkohal välja tõlgenduse, mille kohaselt määratleb ja täidab Sauteri teostes avanevat subjektiivsust eksistentsiaalne tunne. Siinkohal tuginen Matthew Ratcliffe'i (2008, 2012) eksistentsiaalse tunde mõistele, kuid sarnast sõnavara on kasutanud ka teised, nt räägib Edward Relph (1980: 51) oma koha-käsitluses eksistentsiaalsest väljaspoolsusest.

Eksistentsiaalseid tundeid seletatakse sageli mõtlemise eest varju jäävate afektidena, kõikehõlmavate ja kindlasti ka kehaliste seisunditena (Ratcliffe 2012: 27). Nende seisundite ühisnimetajaks on hägune mõttetuse, võõruse tunne, distantseeritus igapäevakogemustest ning teistest inimestest. See käsitus asetub üldisesse afektiivse pöörde konteksti, mille kohaselt on inimlik elu alati emotsionaalselt häälestatud. Selline arusaam on muutunud populaarseks eriti sotsiaalse elu uuringutes (vt Clough, Halley 2007; Hoggett, Thompson 2012), kuid tasub rõhutada, et pööre ulatub tagasi vähemalt eelmise sajandi alguse fenomenoloogiasse. „Olemises ja ajas” rõhutab Heidegger (1967: 134), et inimlik olemasolu (sks Dasein) viibib alati mingis häälestuses/ meeleolus (sks Stimmung). Ka hiline Edmund Husserl jõudis samale seisukohale: eluilm kogemuse universaalhorisondina avaneb alati emotsionaalselt ja „värvib” kõiki teisi kogemusi (vt Lee 1998). ${ }^{6}$

Keskne kategooria, mille kaudu Ratcliffe eksistentsiaalseid tundeid seletab, on võimalikkus. Selle all ei mõelda mitte üksnes abstraktse mõtlemise kategooriaid, vaid ka laiemalt mittekontseptuaalseid, kehalisi, harjumuspäraseid ootusi (Ratcliffe 2012: 29). Eksistentsiaalsete tunnete kaudu ilmneb maailm inimesele oluliste võimalikkuse liikide (praktiline tähenduslikkus, võimalus toimida) puudumisena (Ratcliffe 2012: 31-32). Inimest tabab läbiv (sh kehaline), tahet halvav tunne, et midagi pole võimalik teha, kellegagi ei kuuluta kokku. See tunne halvab ka ajalisuse: tulevik puudub, pole võimalik tunda, et see võib erineda praegusest, kõik on seesama (Ratcliffe 2012: 36). Puudumine ise on kogemuse dominantse osana kohal, tingides seda, kuidas inimene kogeb üldiselt enda viibimist maailmas (Ratcliffe 2012: 35, 48). Eksistentsiaalse tundega inimene ei tunne ennast maailmas kodus, kogemuse

${ }^{6}$ Minu hinnangul on just häälestus (sks Stimmung) eksistentsiaalsete emotsionaalsete seisundite kirjeldamiseks kohasem mõiste, kuid Ratcliffe (2012: 32-33) on erinevatel põhjustel, sh Stimmung'i täpne tõlkimatus inglise keelde, vastupidisel seisukohal. Kuna tuginen vahetult tema käsitlusele, jään siinkohal tunde juurde. 
horisondiline ülesehitus hajub võimatuseks või vähemalt võimaluste kaoseks (Ratcliffe 2012: 33-34).

Ratcliffe'i põhiline fookus eksistentsiaalsete tunnete uurimisel on psühhopatoloogia (Ratcliffe 2008), kuid tema tõlgenduse eelis seisneb selles, et see on ülimalt avar ega taanda nähtust lihtsatele põhjuse-tagajärje skeemidele. Eksistentsiaalse tunde mõiste abil võib hinnanguvabalt kirjeldada seda, mida psühhiaatrid diagnoosivad depressioonina, Heideggeri stiilis ontoloogilisi kogemusi (ängistus, igavus) ja ka klassikaliste eksistentsialistide piir- ja võõrdumiskogemusi. Käesolev artikkel näitas, kuidas Sauteri loomingus avanevad kõik need tunnused, mille kaudu selgitatakse eksistentsiaalset tunnet. Sauteri minategelased on läbivalt ebamäärase võõruse küüsis, millega kaasneb nii võimalikkuste sulgumine kui ka aja kokkutõmbumine tulevikuta igavikuks. Ängistavad seisundid pole pelgalt intellektuaalsed, vaid ka kehalised („Kafkatunne kõhus", Sauter 1998: 82). Leidub isegi kirjakoht, kus peategelane seletab tagantjärele oma minevikulist seisundit eksistentsiaalsete murede käes viibimisena (L: 268 ).

Artiklis analüüsisin Sauteri teostes avanevat eksistentsiaalselt häälestatud subjektiivsust kodutuse mõiste abil. Näitasin, et Sauteri peategelaste põhimiseks asumisviisiks on kodutus kodus, argielu sujuvust tagavate kogemushorisontide püsiv tõrge. Sellise asumisviisiga kaasneb peategelasel ratsionaalselt põhjendamata veendumus maailma juhuslikkuse, elu mõttetuse ja keele sügavama tähendusetuse kohta. Ometi ei hülga Sauteri peategelane mõttetut elu, vaid jätkab eksistentsiaalsete tunnete käes kannatamist ning koduigatsuse tundmist. Artikli teises pooles vaatlesin, milliseid strateegiaid Sauteri teoste peategelane kasutab, kogemaks piinavas eksistentsis kodusushetki. Jõudsin järeldusele, et toimivaim strateegia on sellest mõttetust elust kirjutamine, mis muutub turvaliseks rutiiniks: kirjutamisest saab kodu. Samas ei taotleta enda „elust välja kirjutamist”, vaid vahepealset seisundit elu ja kirjanduse piiril, kirjutamist tasakaalustavaks jõuks on armastus.

Peeter Sauteri teosed kujutavad peategelase kodutut eksistentsi, ilma et sellele antaks üht kindlat põhjuslikku seletust. Artikli lõpus näitasin, et Sauteri loomingut saab tõlgendada paljude teoreetiliste lähtekohtade kaudu, ning pakkusin viimaks põgusalt välja ühe võimaliku seletuse kogu subjektiivsust läbistava eksistentsiaalse tunde abil.

\section{Kirjandus}

Ag a m b e n, Giorgio 1999. Potentialities. Stanford: Stanford University Press.

Annus, Epp 2009. Argiilma poeetika ja pidulik elu. - Methis. Studia humaniora Estonica, nr 4, lk 134-144.

Augé, Marc 2012. Kohad ja mittekohad. Sissejuhatus ülimodernsuse antropoloogiasse. (Bibliotheca controversiarum.) Tlk Anti Saar. Tallinn: Tallinna Ülikooli Kirjastus.

Blanchot, Maurice 1999. From dread to language. - M. Blanchot, The Station Hill Blanchot Reader. Station Hill: Barrytown, lk 343-358.

B os caljon, Daniel 2016. Dwelling beyond poetry: The uncanny houses of Hawthorne and Poe. - Resisting the Place of Belonging. Uncanny Homecomings in 
Religion, Narrative and the Arts. Toim D. Boscaljon. London-New York: Routledge, lk 47-60.

Clough, Patricia Ticineto, Halley, Jean (toim) 2007. The Affective Turn. Theorizing the Social. Durham-London: Duke University Press.

Del e u ze, Gilles 2001. Pure Immanence. Essays on a Life. New York: Zone Books.

Dovey, Kimberly 1985. Home and homelessness. - Home Environments. Toim Irwin Altman, Carol M. Werner. New York: Springer, lk 33-85.

$\mathrm{H}$ a m blet, Wendy 2003. Identity, self-alienation and the problem of homelessness. - Symposium. Canadian Journal of Continental Philosophy / Revue canadienne de philosophie continentale, $\mathrm{kd}$ 7, nr 2, lk 133-142.

He i d e g g e r, Martin 1967. Sein und Zeit. Tübingen: Niemeyer.

Heid e g g e r, Martin 1983. Die Grundbegriffe der Metaphysik. Welt - Endlichkeit - Einsamkeit. Gesamtausgabe. II Abteilung. Kd 29-30. Frankfurt am Main: Vittorio Klostermann.

Heinlo o, Ivo 2009. Flanöör nõukogude provintsipealinnas. Üks vaatenurk Peeter Sauteri romaanile „Indigo”. - Methis. Studia humaniora Estonica, nr 4, lk 89-98.

Hoggett, Paul, Thompson, Simon 2012. Politics and the Emotions. The Affective Turn in Contemporary Political Studies. London-New York: Continuum.

Kraavi, Janek 2016. Transgressiivse kirjanduse poeetikast I. Näiteid eesti nüüdiskirjandusest. - Keel ja Kirjandus, nr 11, lk 817-833.

Kr a mer, Erich Mark, Lee, Soobum 1999. Homelessness: The other as object. Reading the Homeless. The Media's Image of Homeless Culture. Toim Eungjun Min. London: Praeger Publishers, lk 135-157.

Kr i s te v a, Julia 2017. Võõrad iseendale. (Bibliotheca controversiarum.) Tlk Kaia Sisask. Tallinn: Tallinna Ülikooli Kirjastus.

Kr u 11, Hasso 2000. Ülevus ja anarhia. Peeter Sauteri ligimese proosa. - H. Krull, Millimallikas. Kirjutised 1996-2000. Tallinn: Vagabund, lk 91-114.

Lee, Nam-In 1998. Edmund Husserl's phenomenology of mood. - Alterity and Facticity. New Perspectives on Husserl. Toim Natalie Depraz, Dan Zahavi. Dordrecht: Springer, lk 103-120.

Li p p ing, Jüri 2016. Tulgu mis tuleb. Agambeni täitmata ruumide passiivne fantaasia. - J. Lipping, Raamat nimega iha. Valik tekste 1997-2016. Tartu: EYS Veljesto, lk 221-236.

Luks, Leo 2013a. Ilma kodutundeta me jääme kodutuks. - Akadeemia, nr 3, lk $402-427$.

Luks, Leo 2013b. Kas kodutus on moodsa aja normaalseisund? - Akadeemia, nr 6, lk 1111-1130.

Luks, Leo 2014. Eesti kirjanduse kadunud kodu. - Keel ja Kirjandus, nr 10, lk $729-748$.

L u ks, Leo 2015. Nihilism ja kirjandus. $E i$ kogemine filosoofia ja kirjanduse ühtesulamisel. (Acta Universitatis Tallinnensis. Humaniora.) Tallinn: Tallinna Ülikooli Kirjastus.

Luks, Leo 2018. Ebaõdus kojutulek eesti kirjanduses. - Keel ja Kirjandus, nr 3, lk 177-198.

Ly otard, Jean-François 1991. Domus and the Megalopolis. - J-F. Lyotard, The Inhuman: Reflections on Time. Cambridge: Polity Press, lk 191-204. 
Männiste, Indrek 2013. Henry Miller: The Inhuman Artist. A Philosophical Inquiry. New York: Bloomsbury.

Pall a m a a, Juhani 2008. Existential homelessness - placelessness and nostalgia in the age of mobility. - The Ethics of Mobilities. Rethinking Place, Exclusion, Freedom and Environment. Toim Sigurd Bergmann, Tore Sager. Hampshire, Burlington: Ashgate, lk 143-156.

Ratcliffe, Matthew 2008. Feelings of Being: Phenomenology, Psychiatry and the Sense of Reality. Oxford-New York: Oxford University Press.

Ratcliffe, Matthew 2012. The phenomenology of existential feeling. - Feelings of Being Alive. Toim Joerg Fingerhut, Sabine Marienberg. Berlin: De Gruyter, lk 23-54.

Relph, Edward 1980. Place and Placelessness. London: Pion Limited.

S a u t er, Peeter 1990. Indigo. Tallinn: Eesti Raamat.

S a u ter, Peeter 1997. Luus. Tallinn: Maa.

S a u ter, Peeter 1998. Kogu moos. Tallinn: Tuum.

S a u t er, Peeter 2001. Euroopa hulgus. Tallinn: P. Sauter.

S a u t e r, Peeter 2005. Hispaania saapad ja silmad. Tallinn: P. Sauter.

S a u t er, Peeter 2008. Beibi bluu. Tallinn: Tuum.

S a u t e r, Peeter 2011. Flirt budaga. Elust ja tsiklisõidust. Tallinn: Go Group.

S a u ter, Peeter 2012. Märkmeid vaeste kirjanike majast. Poeem. Tallinn: Kirjanik.

S a u t e r, Peeter 2014. Koer ostab kassitoitu. Tallinn: Kirjanik.

S a u t e r, Peeter 2015. Pannkoogid üksinduses. Tallinn: Kirjanik.

S a u t e r, Peeter 2016. Sa pead kedagi teenima. Tallinn: Tuum.

S a u t e r, Peeter 2018. Kodusõdur. Tallinn: Kirjanik.

S ering, Paula 1992. „Olla eikeegi eimiskis”: Peeter Sauteri proosa. - Vikerkaar, nr 5, lk 47-51.

Sibley, David 1995. Geographies of Exclusion. Society and Difference in the West. London-New York: Routledge.

Tolst oi, Lev 1957. Anna Karenina. Esimesest kuni neljanda jaoni. - L. Tolstoi, Kogutud teosed, VIII kd. Tallinn: Eesti Riiklik Kirjastus.

W a r d h a u h, Julia 1999. The unaccomondated woman: home, homelessness and identity. - The Sociological Review, kd 47, nr 1, lk 91-109.

Leo Luks (snd 1976), PhD, Eesti Maaülikooli filosoofiadotsent (Fr. R. Kreutzwaldi 1, 51006 Tartu); Tartu Herbert Masingu kooli filosoofia õpetaja, leoluks@hot.ee

\section{Homelessness in one's own home as reflected in Peeter Sauter's oeuvre}

Keywords: homelessness, phenomenology, existential feelings, Peeter Sauter

The article analyses a feeling of being homeless in one's own home, a feeling experienced without a clear problem or compelling reason. The study rests on a phenomenological approach to homelessness. Part One of the article describes such experience of homelessness as depicted by Peeter Sauter by using his protagonists's inner voice, which is followed by an analysis of the spatial, intersubjective and 
operational aspects of the experience. Part Two deals with a homeless, estranged subjectivity and how such a subject defines its position in the universe. Part Three discusses the strategies used by the protagonists to cope with their permanent condition of feeling homeless, which leads to the analysis of writing as one of the main coping strategies in Part Four. In Part Five the condition of Sauter's protagonist is interpreted by means of the concept of existential feelings, with brief reference to some other possible interpretations. The analysis demonstrates that the main condition of Sauter's I-figures is feeling homeless in their own home, a persistent failure of the experiential horizons meant to ensure a smooth flow of the everyday life. In Sauter's main characters that condition is accompanied by a rationally unfounded conviction that the world is accidental, life is meaningless and lack of signification runs deep in language. And yet Sauter's characters do not abandon this meaningless life, but persist in suffering from existential feelings and pining for home.

Leo Luks (b. 1976), PhD, Estonian University of Life Sciences (Fr. R. Kreutzwaldi 1, 51006 Tartu), Associate Professor of Philosophy; Herbert Masing School, Tartu, Teacher of Philosophy, leoluks@hot.ee 